\title{
Development of the Android-Based Interactive Physics Mobile Learning Media (IPMLM) with Scaffolding Approach on the Sound Wave to Improve Student Learning Independence
}

\author{
R N Tuada ${ }^{1 *}$, Suparno ${ }^{1}$ \\ ${ }^{1}$ Ephysics Education, Graduat School Program, Universitas Negeri Yogyakarta, \\ Jl. Colombo 1 Yogyakarta, Indonesia \\ *Email: rasydahnur.2018@student.uny.ac.id
}

\begin{abstract}
This study aims to: 1) produce an Android-based IPMLM application that is suitable for learning on sound wave material, 2) test the effect of IPMLM on student learning independence. This type of research is the R\&D of 4-D models (defining, developing, developing, and disseminating). The application of this research uses the Scaffolding approach. Research design uses Pre-Test Post-Test Control Group. IPMLM applications are rated by media and materials experts. The limited trial stage for the readability of IPMLM media was carried out at SMAN 1 Woha class 11 IPA with a total of 30 students. The limited trial stage was carried out at SMAN 1 Woha, SMAN 1 Palibelo, SMAN 1 Belo, and SMAN 1 Bolo with a total of 320 students in class 11 of the science program. The subjects of the broad test were students of class 11 IPA from SMAN 1 Woha, SMAN 1 Palibelo and SMAN 1 Belo, each of which consisted of two classes in the experimental class and the control class. The number of students in the experimental class was 88 students and the control class was 90 students. Subjects were selected by purposive sampling technique. The broad test research design used a Pretest-Posttest Control Group. Data collection was carried out by means of a questionnaire. The results show that 1) the IPMLM application is suitable for use in learning physics about sound waves, 2) the use of IPMLM in learning physics increases student learning independence.
\end{abstract}

Keywords: Interactive Physics Mobile Learning Media, Scaffolding approach, learning independence, Android.

\section{INTRODUCTION}

Indonesia faces challenges in the Industrial Revolution 4.0, one of which is the readiness of human resources [1, 2]. Ideally, good human resources have technological skills, digital literacy, creativity, innovation, and high intelligence. However, according to The Global Creativity Index 2015 ranked Indonesia creativity is still on the order of 115 out of 139 with a score of 0.202 out of a maximum score of 1.00 [3]. In line with these data, the innovation index according to the Global Innovation Index 2019 shows Indonesia is in the order of 85 out of 129 countries and a score of 29.72 from a maximum score of 100.00 [4]. Meanwhile, in the context of science, the performance of Indonesian students according to PISA 2015 is in the order of 65 out of 73 countries [5]. This means that the creativity and innovation of the Indonesian people are still very low and serious efforts are needed to improve them.

In the context of science learning, the ability of high school students is also very low. At the 2018/2019 National Examination, the average national physics UN score was 45.79 from the maximum value of 100.00 where this value is in a low category [6]. Moreover, the physics UN score of high school students in Bima regency on average only reached 36.01 of the maximum value of 100 [6]. Physics materials with low absorption capacity are waves and optics with a national presentation of $44.42 \%$ and the Bima regency level of $35.96 \%$ [6]. The absorption power of sound wave 
material is the lowest among other physical materials. Based on research it shows $77.7 \%$ of students stated that sound wave material is a material that is difficult to learn [7]. Students experience many misconceptions in understanding the concept of sound propagation through the medium to the listener's ears [8]. Another factor that affects the low absorption of students in sound wave material is too many equations, increasing the chance of misconceptions [9]. This condition certainly hinders the improvement of quality human resources.

In general, students in Indonesia master routine questions, simple computation, and measure knowledge of facts in daily contexts but have not been able to integrate information, draw conclusions, and generalize their knowledge to other things [10]. This is due to the learning system which is a student center so that the learning independence of students is low. Students experience dependence on other people, especially teachers because they think that teachers are the only source of knowledge so that independent learning is less trained [11]. Lack of independent learning among students is related to poor study habits, including just learning after an exam, cheating, and looking for leaks of exam questions. Low-performing students and low selfesteem are less able to benefit from the learning resources used [12]. Learning independence will be realized if students have control over personal awareness, motivation, competence, and skills that they will achieve [13]. Students who are able to learn independently have greater potential to achieve high academic achievement because they have the ability to identify and choose their own problems, plan activities, and propose results at the end of activities [14;15]. Learning independence possessed by students is able to make them make decisions in the learning process so that they can be accountable for the decisions they make [16].

Therefore, to increase the learning independence of high school students in Bima, the researcher developed Interactive Physics Mobile Learning Media (IPMLM) with a scaffolding approach to sound wave material. IPMLM is developed so that students can follow the development of digital technology. This media is intended as a learning resource. Interactive smartphone applications are designed so that students can feel happy in learning physics, and not easily get bored. IPMLM features include teaching materials, LKPD, practice questions, and evaluation. In its implementation in the IPMLM field, it is carried out with a scaffolding approach. the scaffolding approach is designed so that students gradually have high independence abilities with reduced assistance.

This template, modified in MS Word 2007 and saved as a "Word 97-2003 Document" for the PC, provides authors with most of the formatting specifications needed for preparing electronic versions of their papers. All standard paper components have been specified for three reasons: (1) ease of use when formatting individual papers, (2) automatic compliance to electronic requirements that facilitate the concurrent or later production of electronic products, and (3) conformity of style throughout a conference procedings.

\section{RESEARCH METHODS}

This development uses a 4D research whit stage of the Defining, Designing, Developing, and Disseminating. The aim is to see the feasibility and influence of the Interactive Physics of Moving Learning Media with a scaffolding approach on the Sound Wave Material to improve student learning independence. In the first stage, the researcher conducted an initial analysis related to needs analysis and literature review. The second stage, research instruments, and IPMLM. The technique of running data is in the form of non-tests. Non-test techniques are in the form of Independent Learning questionnaires, product feasibility transportation. The third stage includes several stages, namely the feasibility test and validation of learning media consisting of material experts, media experts, and physics teachers. Test the validation of the questionnaire instrument by experts. Then the empirical test of the learning independence questionnaire was tested on a limited basis on students and the limited trial of learning media using student sheets.

IPMLM learning media trial was carried out independently by 30 students of class XI IPA at SMAN 1 Woha. Subjects were selected by purposive sampling technique. The learning independence questionnaire instrument was carried out on 320 students of class XII IPA at SMAN 1 Woha, SMAN 1 Palibelo, SMAN 1 Belo and SMAN 1 Bolo. Respondents are selected based on students who have studied the sound wave material. An extensive test was conducted to see the increase in student learning independence after the IPMLM learning media. The subjects of the broad test were students of grade 11 science from SMAN 1 Woha, SMAN 1 Palibelo and SMAN 1 Belo, each of which consisted of each class consisting of an experimental class and a control class. The number of students in the experimental class was 88 students and the control class was 90 students. The last stage is the dissemination, namely the dissemination of applications and research results in the form of HKI and scientific publications.

The instrument for measuring learning independence used a questionnaire. The questionnaire was prepared based on five indicators, namely selfconfidence, ability to solve problems, responsibility, initiative, and discipline. The questionnaire is presented in the form of a statement using responses in the form of a Likert scale. The Likert scale used is a scale of 1-4. 
The research design used in the broad test was the Pretest-Posttest Control Group Design as shown in Table 1. Where $\mathrm{O} 1$ was a pretest, $\mathrm{O} 2$ was a posttest, $\mathrm{X} 1$ was learning by using IPMLM media with a scaffolding approach, and X2 was learning using PPT.

Table 1.Pretest-Posttest Control Group Design

\begin{tabular}{|l|c|c|c|}
\hline \multicolumn{1}{|c|}{ Class } & Pre-test & Treatment & Post-test \\
\hline Experiment & $\mathrm{O}_{1}$ & $\mathrm{X}_{1}$ & $\mathrm{O}_{2}$ \\
\hline Control & $\mathrm{O}_{1}$ & $\mathrm{X}_{2}$ & $\mathrm{O}_{2}$ \\
\hline
\end{tabular}

The lesson plan was developed by integrating three levels of scaffolding adapted from Anghileri [17] and combined with the IPMLM learning media. The teacher acts as a facilitator in guiding students so that they can complete the assignment given. In the first level, the teacher prepares students to be ready to take part in learning by providing perceptions and motivation as well as learning objectives to be carried out. In the second level, the teacher explains the concept of sound waves using IPMLM media. Besides, the teacher guides students in completing LKPD. The final stage is to develop conceptual thinking. At this level, the teacher and students conclude the sound wave material that has been studied. The relationship between IPMLM, the Scaffolding approach, and independent learning is shown in table 2 .

Table 2. Relationship between IPMLM, Scaffolding approach, and Student learning independence.

\begin{tabular}{|c|c|c|c|}
\hline Level Scaffolding & \multicolumn{2}{|c|}{ IPMLM } & Independence in Learning \\
\hline $\begin{array}{l}\text { environmental } \\
\text { provisions }\end{array}$ & \multirow[t]{4}{*}{ material } & \multirow[t]{2}{*}{ Text } & $\begin{array}{l}\text { Students can answer questions from the } \\
\text { teacher confidently }\end{array}$ \\
\hline \multirow[t]{5}{*}{$\begin{array}{l}\text { explaining, reviewing, } \\
\text { and restructuring }\end{array}$} & & & \multirow{2}{*}{$\begin{array}{l}\text { Students can foster an attitude of responsibility } \\
\text { by paying attention to the material and videos } \\
\text { presented in IPMLM. }\end{array}$} \\
\hline & & Video & \\
\hline & & Teacher Chat & $\begin{array}{l}\text { Students can ask the teacher if there is a } \\
\text { material that has not been understood so that it } \\
\text { fosters an attitude of the initiative. }\end{array}$ \\
\hline & \multirow[t]{2}{*}{ LKPD } & Simulation & $\begin{array}{l}\text { Students can foster an attitude of initiative and } \\
\text { problem-solve in solving given problems. }\end{array}$ \\
\hline & & $\begin{array}{l}\text { Discussion } \\
\text { Sheets }\end{array}$ & $\begin{array}{l}\text { Students can foster an attitude of the initiative, } \\
\text { problem-solving, responsibility, and discipline in } \\
\text { completing assigned tasks. }\end{array}$ \\
\hline \multirow[t]{2}{*}{$\begin{array}{l}\text { Developing conceptual } \\
\text { thinking }\end{array}$} & \multirow[t]{2}{*}{ Evaluation } & Exercise & $\begin{array}{l}\text { Students can foster a confident attitude, and } \\
\text { problem-solving in solving practice questions. }\end{array}$ \\
\hline & & Discussion & $\begin{array}{l}\text { Students can foster a confident attitude by } \\
\text { expressing their opinions. }\end{array}$ \\
\hline & & & \\
\hline
\end{tabular}

The validity of the contents of each item of the independent learning questionnaire is known through the v'aiken coefficient. The QUEST program was used to determine the validity and reliability of the independent learning questionnaire based on the results of empirical tests. The question items are said to be compatible with the PCM model if the MNSQ infit value is $\geq 0.77$ and $\leq 1.30$ [18].

The feasibility of the media is assessed from several aspects, namely software engineering, visual communication, interactivity, ease, and flexibility of access. The feasibility of the material contained in the IPMLM is assessed from two aspects, namely learning and material structure. In addition, students gave responses regarding the readability of the media covering four aspects, namely content, presentation, graphics, and language. The data from the feasibility assessment were analyzed using descriptive analysis. The average score for each aspect of the feasibility assessment learning tool converted to a five scale [19] the average score for each aspect of the assessment criteria were changed to values in Table 3. 
Table 3. Criteria for Assessment Results Five Scale

\begin{tabular}{|c|c|}
\hline Respondent Scores & Category \\
\hline $\mathrm{X} \geq \mathrm{Xi}+1.8 \mathrm{SBi}$ & Very Good \\
\hline $\mathrm{Xi}+0.6 \mathrm{SBi}<\mathrm{X} \leq \mathrm{Xi}+1.8 \mathrm{SBi}$ & Good \\
\hline $\mathrm{Xi}-0.6 \mathrm{SBi}<\mathrm{X} \leq \mathrm{Xi}+0,6 \mathrm{SBi}$ & Enough \\
\hline $\mathrm{Xi}-1.8 \mathrm{SBi}<\mathrm{X} \leq \mathrm{Xi}-0.6 \mathrm{SBi}$ & Vess Less \\
\hline $\mathrm{X} \leq \mathrm{Xi}-1.8 \mathrm{SBi}$ & Very \\
\hline
\end{tabular}

The effectiveness of using IPMLM is known by looking at the differences in the ability and increased learning independence of experimental and control class students. The data were obtained from a learning independence

\section{RESULT AND DISCUSSION}

\subsection{Defining Stage}

The initial stage in the research is to conduct a preliminary study in the form of literature and field studies. A literature study is carried out by reviewing research articles. The results showed that the learning independence of students allowed them to make decisions in the learning process so that they could be accountable for decisions made to achieve their learning achievement [16]. Field studies were carried out through observations and open interviews with teachers at SMAN 1 Palibelo, SMAN 1 Woha, and SMAN 1 Belo. The results of field observations show that the curriculum used is the 2013 curriculum. Teachers have not fully utilized technology in the learning process. Meanwhile, schools are not yet equipped with technological media such as LCDs and projectors that enable innovative learning. In addition, information was obtained that all students use smartphones. Each school implements a different policy on the use of smartphones in schools. SMAN 1 Palibelo implements a policy where the use of smartphones is only done when learning requires internet access. SMAN 1 Belo the use of smartphones is carried out according to the teacher's policy for each subject. Unlike the case with SMAN 1 Woha where students are given the freedom to use smartphones while helping the implementation of learning. Based on these conditions, innovative learning media that are familiar to students are developed, namely media in the form of interactive android applications. questionnaire that had been filled in by students before and after learning. Calculation of data using mixed ANOVA with the help of SPSS.

\subsection{Designing Stage}

This stage the product is designed in the form of a flowchart and storyboard which contains an overview of the application being developed. The flow chart is used to determine what will be displayed on the learning media. Furthermore, a storyboard is designed which contains the scene of the application being developed. Content planning in the media that is instructions for use, competence, material, LKPD, evaluation, and developer profiles. In addition, this application is also equipped with a teacher chat feature that allows teachers and students to provide feedback to each other about learning material.

Learning independence questionnaire measurement instruments were also developed. The learning independence of students is measured using a questionnaire with an ordinal scale of 1 to 4 . The questionnaire consists of 26 statement items and is developed based on the independent learning aspect. The assessment and measurement instruments developed were validated by expert lecturers, physics teachers, and peers.

\subsection{Developing Stage}

At this stage, further development of the flow chart and storyboard that has been made is carried out so as to produce a complete form of the developed IPMLM application. As for the appearance of the IPMLM application after being developed using Android Studio, a display is obtained as in Figure 1, Figure 2, Figure 3, Figure 4. 


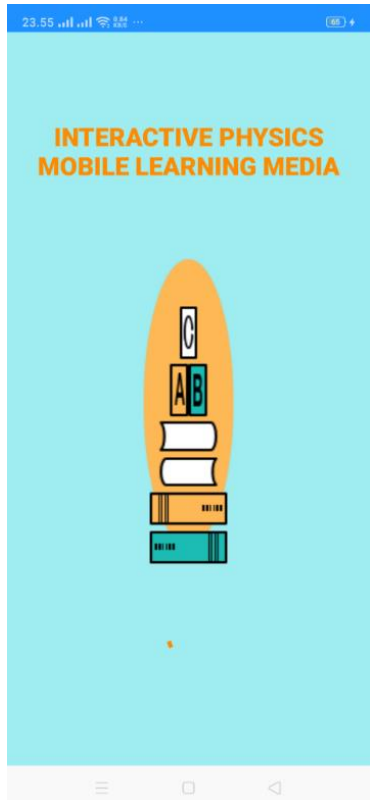

Figure 1 Start Page View

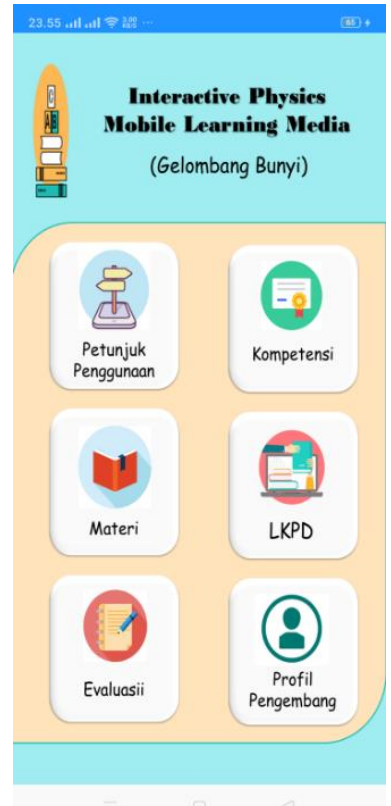

Figure 2 Main Menu Display

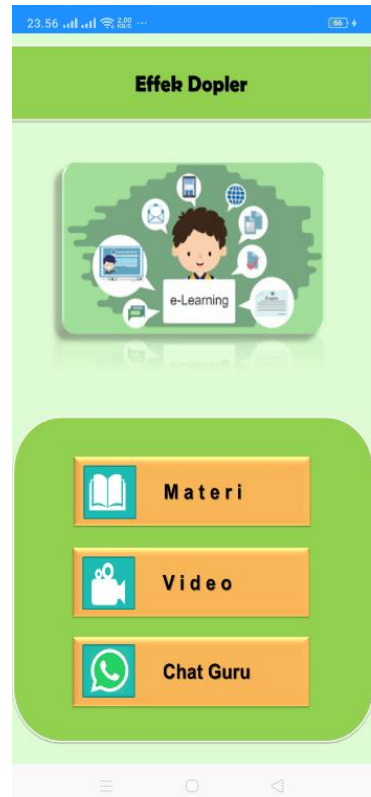

Figure 3 Material Menu Display

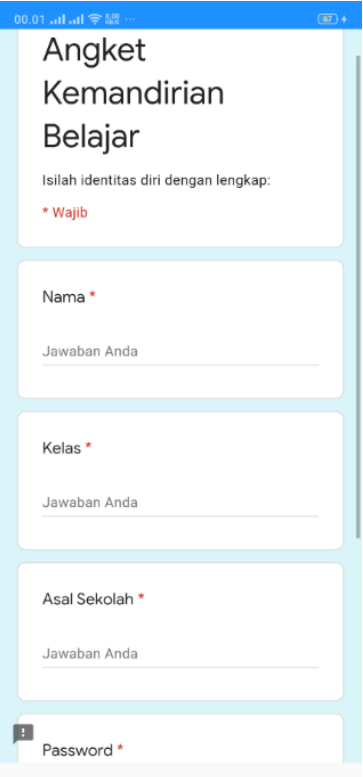

Figure 4 Learning Independence Questionnaire Display

\subsubsection{Results of Validation of IPMLM Media The IPMLM}

The application was assessed for its feasibility by 1 media expert lecturer and 1 material expert. The media were assessed using a questionnaire with a yes-no answer choice. The results obtained are shown in Table 4.

Table 4. Results of Validation of IPMLM Media The IPMLM

\begin{tabular}{|c|c|c|c|}
\hline Category & $\begin{array}{l}\text { Aspects } \\
\text { Assessed }\end{array}$ & Score & Category \\
\hline \multirow[t]{4}{*}{ Madia } & $\begin{array}{l}\text { Software } \\
\text { Engineering }\end{array}$ & 94 & Very Good \\
\hline & $\begin{array}{l}\text { Visual } \\
\text { Communication }\end{array}$ & 88 & Very Good \\
\hline & Interactivity & 90 & Very Good \\
\hline & $\begin{array}{l}\text { Ease and } \\
\text { Flexibility }\end{array}$ & 94 & Very Good \\
\hline \multicolumn{2}{|c|}{ Average } & 91 & Very Good \\
\hline Material & Learning & 89 & Very Good \\
\hline
\end{tabular}

\begin{tabular}{|l|l|l|l|}
\hline $\begin{array}{l}\text { Material } \\
\text { Structure }\end{array}$ & 87 & Very Good \\
\hline Average & 88 & Very Good \\
\hline
\end{tabular}

Table 4 shows that every aspect of the media and material category reaches the "very good". This shows that the IPMLM application is suitable for use in learning physics sound wave material by the revisions suggested by the assessors.

\subsubsection{IPMLM Media Readability Results by Students}

The IPMLM media readability trial was conducted on 30 students of class XI IPA. The data collection instrument was a yes-no questionnaire. The results obtained are shown in table 5.

Table 5. Results of Readability of IPMLM Media by Students

\begin{tabular}{|l|l|l|}
\hline Aspects Assessed & Score & Categories \\
\hline Content & 89 & Very Good \\
\hline Presentation & 90 & Very Good \\
\hline Graphic & 91 & Very Good \\
\hline Language & 87 & Very Good \\
\hline
\end{tabular}




\begin{tabular}{|l|l|l|}
\hline Average & 89 & Very Good \\
\hline
\end{tabular}

Table 4 shows that readability media in every aspect fulfills the achievement criteria of $70<\mathrm{X} \leq 85$ with very good category [19]. So it can be concluded that IPMLM is suitable for use as a learning medium in the classroom.

\subsubsection{The validity and reliability of the learning independence questionnaire.}

The learning independence questionnaire instrument was validated through two stages, namely the validity of the content by experts and empirical tests. Content validity using V'aiken. Referring to Aiken's (V) validity coefficient table, the minimum value accepted with an error rate $\alpha=1 \%$ is 0.86 (Aiken, 1985). The results of the content validation show that the validity coefficient (V) of each independent learning questionnaire statement is more than the minimum value of 0.86 with the lowest value $\mathrm{V}=0.90$ and the highest value $\mathrm{V}=1.00$. This shows that all statements of learning independence are valid.

The results of the empirical test show that each item fits the model partial credit model (PCM). All items of the questionnaire statement of learning independence are within the acceptance limit of $\geq 0.77$ to $\leq 1.30$. The items have fit the model if the MNSQ infit value is between 0.77 to 1.30 and the MNSQ outfit value is between 0.5 to $1.5[20]$.

The reliability of the independent learning instrument can be seen through the estimation of item reliability and case/person reliability in the QUEST output. The reliability of the test shows whether the test score can describe the ability of students who take the test. Table 6 shows the statistical summary of the results of independent learning.
Table 6 Instrument reliability estimates for learning independence.

\begin{tabular}{|c|c|}
\hline Reliability & Coefficient of reliability \\
\hline Summary of item estimates & 0.82 \\
\hline Summary of case estimates & 0.76 \\
\hline
\end{tabular}

Table 6 shows that the value of person reliability is 0.76 and item reliability is 0.82 . Based on the criteria stated by Sumintono \& Widhiarso [21], this value indicates that the statements in the independent learning questionnaire are quite reliable. The consistency of students' answers is also quite good. This shows that students do not answer carelessly. Overall, the learning independence questionnaire developed is feasible to be used in measuring the level of learning independence of students.

\subsubsection{Test Results of the Effectiveness of the Use of IPMLM on the Learning Independence of Students Learning}

Independence is one of the factors that affect student learning outcomes. The learning process, both in the control class and in the experimental class, is expected to increase the learning independence of students. The learning independence of students is measured before learning to determine the early learning independence of students. Furthermore, after participating in the learning as many as 3 meetings the students' learning independence was measured again. Learning independence is measured using a questionnaire with a scale of $1-4$, which consists of positive statements and negative statements.

The difference in learning independence in the experimental class and the control class can be found out with the SPSS Output Test of Between-Subject Effect. The results of differences in learning independence in the two classes are shown in Table 7. Tthat the difference between the experimental class and the control class obtained a significance of $0,000<\alpha(0.05)$ which means $\mathrm{HO}$ is rejected. So there are significant differences independence of learners in the class using IPMLM with approach scaffolding with students who did not use PPT media.

Table 7 Test Results of Between-Subject Effects for Independent Learning

\begin{tabular}{|l|l|l|l|l|l|}
\hline Source & Dependent Variable & df & Mean Square & F & Sig. \\
\hline Corrected Model & Independence_Learning & 3 & 3214,988 & 80,235 & 0,000 \\
\hline Intercept of & Independence_Learning & 1 & 1837448,438 & 45856,614 & 0,000 \\
\hline Class & Independence_Learning & 1 & 1559,318 & 38,915 & 0,000 \\
\hline
\end{tabular}


The increase in the ability to learn independence can be seen through the significance and magnitude of the mean difference (MD). Table 8. shows the results of pairwise comparisons for the ability of Learning Independence.

Table 8 Pairwise Comparisons Ability of Learning Independence

\begin{tabular}{|c|c|c|c|c|c|}
\hline Class & $\begin{array}{c}\text { (I) } \\
\text { Time }\end{array}$ & $\begin{array}{c}(J) \\
\text { Time }\end{array}$ & Mean Difference (IJ) & Std. Error & Sig. \\
\hline Experiment & Pre-Test & Post-Test & $-12,216^{*}$ & 0.861 & 0,000 \\
\hline Control & Pre-Test & Post-Test & $-5,812^{*}$ & 1,026 & 0,000 \\
\hline
\end{tabular}

Table 8 shows that the increase in the pretest-posttest ability to independent learning for the experimental class and the control class obtained a significance of $0.000<\alpha$ (0.05) which means $\mathrm{H} 0$ is rejected. This shows that there is a significant increase between the pretest-posttest scores on the ability to independent learning in the experimental class and the control class. Table 5 also shows that the mean difference (MD) value for the experimental class is $\mathrm{MD}=-12,216$ and the control class is $\mathrm{MD}=-5,812$. The mean difference $(\mathrm{MD})$ value indicates that the pretest score minus the negative posttest score for each group. So, the mean posttest score is higher Table 9 Results of the GLM for Student Learning Independence

\begin{tabular}{|c|l|r|r|c|}
\hline \multicolumn{1}{|c|}{ Student Abilities } & \multicolumn{1}{|c|}{ Class } & F & Sig. & Partial Eta Squared \\
\hline Independent Learning & Experiment & 201,475 & 0,000 & 0,54 \\
\cline { 2 - 5 } & Control & 32,076 & 0,000 & 0,15 \\
\hline
\end{tabular}

Table 9 shows that the effective contribution of the experimental class using Android-based IPMLM media with the scaffolding approach in increasing learning independence was 54\%. Meanwhile, the contribution to the control class using Problem Based Learning model assisted by PPT media in increasing learning independence was $15 \%$. than the pretest score, which means that there is an increase between the pretest-posttest scores for learning independence in the experimental class and the control class. The mean difference (MD) value also shows an increase in the pretest-posttest score of the ability to learn independence in the experimental class to be greater than the control class.

The use of IPMLM media with sound wave material with a scaffolding approach contributes effectively to HOTS ability and students' learning independence. Specifically, this is shown in Table 9. 


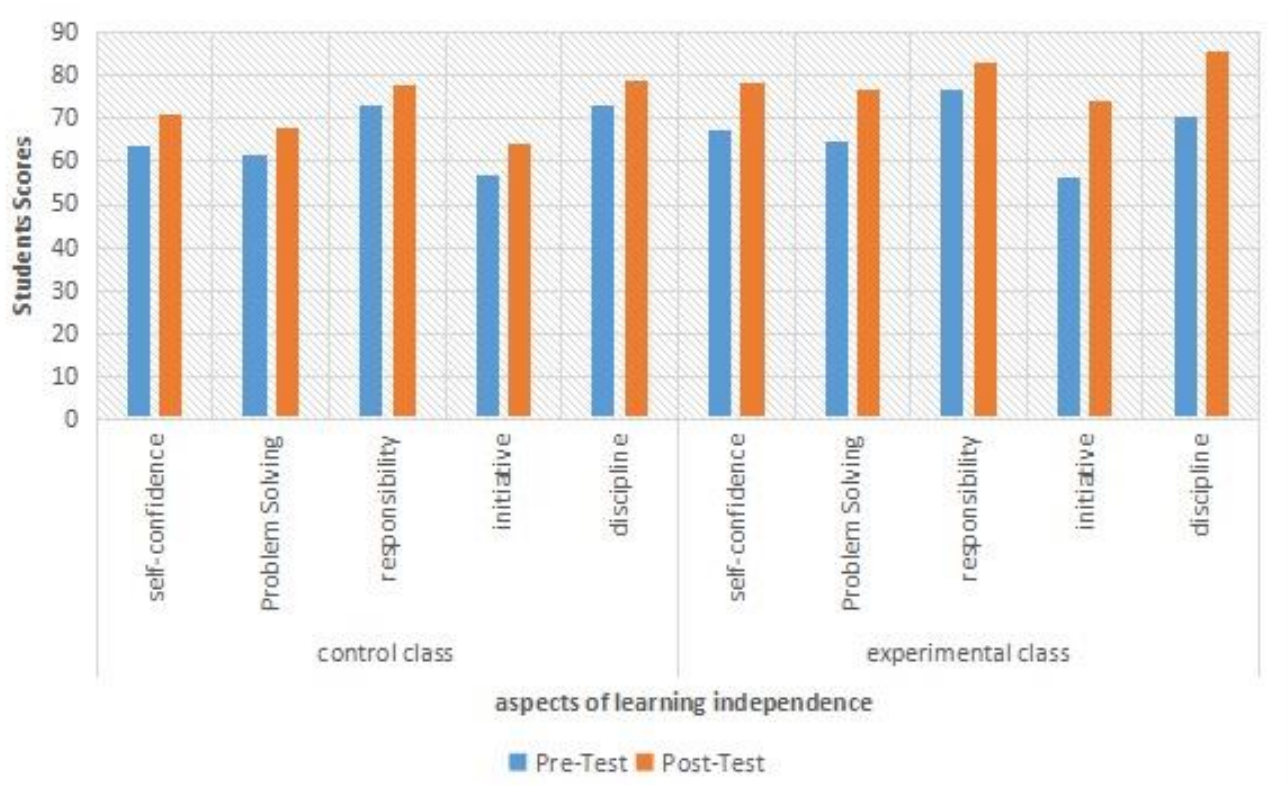

Figure 5 Average Learning Independence of Students Before and After Learning in the Control Class and Experiment Class

Figure 5 shows that every aspect of the independent learning of students in the control class and experimental class has increased. Confidence aspect in the control class increased by 7.39 and in the experimental class by 10.84 ; The aspect of being able to solve problems in the control class has increased by 6.47 and in the experimental class by 12.23 ; Responsibility aspect in the control class has increased by 4.94 and in the experimental class by 6.25 . The initiative aspect in the control class has increased by 7.17 and in the experimental class by 17.64. The discipline aspect in the control class has increased by 6.28 and in the experimental class by 15.26 . These results indicate that the increase in learning independence in the experimental class is better than the control class. This is also evidenced by the results of the GLM test which show that the increase in learning independence of experimental class students is $54 \%$ while the control class is $15 \%$. In the experimental class, the learning uses IPMLM media with a scaffolding approach, while in the control class only uses PPT media. This shows that the use of mobile media has a positive effect on increasing student learning independence. This is in line with the results of research by Arista and Kuswanto [22] that learning using Android-based ViPhyLab technology media can increase student learning independence.

The use of IPMLM affects students' learning independence. IPMLM was developed so that it can be used on Android-based mobile devices. The use of mobile devices as a learning tool that allows students to access learning content flexibly without time constraints [23]. Thus, students can study whenever they want without having to come face to face with the teacher. Animated videos contained in IPMLM media enable students to understand the concept more clearly. Besides, the preparation of sample questions and systematic discussion according to the learning objectives makes it easier for students to understand the questions. Exercise questions also presented in the IPMLM media provide opportunities for students to practice their understanding of the concept of sound waves. This can reduce student dependence on teachers so that students can improve their ability to solve problems. Student learning independence can be improved through fun learning, assignments that can be done independently, and the design of systematic learning activities [22]. This is supported by the use of multimedia in learning to make it easier for students to understand information [24].

Learning activities carried out using IPMLM with a scaffolding approach make students active. One of the activities carried out is that students work in groups to complete LKPD. This practice trains students' responsibility to complete the given task. Students discuss solving problems faced and present the results in front of the class. Students must complete the task on time to practice discipline. In practice, the teacher assists (scaffolding) to students and reduces it slowly. This is done so that students can foster an attitude of the initiative. The interactions that occur between teachers and students during the learning process can increase student motivation and measure the extent to which students can understand the material being taught [25]. The implementation of the scaffolding approach makes students actively involved during learning [24]. This is in line with the research of Azefedo and Hadwin [26] which states that the use of scaffolding supports independent learning. In this case, students can make decisions, organize the course of the investigation, solve the problems faced, and build their thinking [27]. Especially in young people, the use of wireless and cellular 
technology can stimulate learning, support interest, and enhance the learning and development process [28].

\subsection{Disseminating stage}

The last stage is to disseminate the IPMLM application through the play store. Besides, the creation of HKI related to the media. Finally, presenting research results through scientific publications.

\section{CONCLUSION}

This research describes the development of Interactive Physics Mobile Learning Media (IPMLM) based on android with a sound wave scaffolding approach to improve Student Learning Independence. Based on the results obtained, it can be concluded that (1) Androidbased IPMLM with the Scaffolding approach in the resulting sound wave material is feasible to use in increasing the learning independence of students, (2) Android-based IPMLM with a Scaffolding approach on the resulting sound wave material is proven effective to increase the learning independence of students. On the next occasion, the teacher can use IPMLM as an alternative in the use of technology for learning combined with the scaffolding approach and other learning models.

\section{ACKNOWLEDGMENT}

The author would like to thanks for funding support from the Directorate of Research and Community Service (DRPM). Ministry of Research, Technology, and Higher Education of the Republic Indonesia.

\section{REFERENCES}

[1] Fauzan, R. (2018). Karakteristik Model dan Analisa Peluang-Tantangan Industri 4.0. Phasti, $4(01)$, $1-11$. https://doi.org/10.46365/pha.v4i01.271

[2] Satya, V. E. (2018). Kajian Singkat Terhadap Isu Aktual Dan Strategis Strategi Indonesia Menghadapi Industri 4.0. Jakarta : Pusat Penelitian Badan Keahlian DPR RI.

[3] Florida, R., Mellander C., King K.. (2015). The Global Creativity Index 2015. Toronto: Martin Prosperity Institute.

[4] Cornell University, INSEAD, and WIPO. (2019). The Global Innovation Index 2019: Creating Healthy Lives-The Future of Medical Innovation. Geneva: WIPO.

[5] OECD. (2016). PISA 2015 Results (Volume I): Excellence and Equity in Education. Paris: PISA, OECD

Publishing. https://doi.org/10.1787/9789264266490

[6] Kemdikbud, Puspendik. B. (2019). Laporan Hasil Ujian Nasional. Jakarta: Pusat Penilaian Pendidikan.

[7] Hasanah, T.A.N., Huda, C.dan Kurniawati, M. (2017). Pengembangan Modul Fisika Berbasis Problem Based Learnig (PBL) Pada Materi Gelombang Bunyi Untuk Peserta didik SMA Kelas XII. Physich Education Journal. Vol.1 , No. $\quad 1 . \quad 56-65$. https://doi.org/10.21067/mpej.v1i1.1631

[8] Sadgolu, G.P. (2013). $9^{\text {th }}$ grade student's mental models about the sound concept. International Journal Of Education Research And Tecnology.

[9] Sulistyarini, E. (2015). Pengembangan Bahan Ajar Fisika SMA Materi Gelombang Bunyi Berbasis Interactive. Semarang: Universitas Negeri semarang.

[10] Rachmayani, D. (2014). Penerapan Pembelajaran Reciprocal Teaching untuk Meningkatkan Kemampuan Komunikasi Matematis dan Kemandirian Belajar Matematika Peserta didik. Jurnal Pendidikan Unsika. Vol 2, No. 1.

[11] Tuada, R. N., Kuswanto, H., Saputra, A. T., \& Aji, S. H. (2020, January). Physics mobile learning with scaffolding approach in simple harmonic motion to improve student learning independence. In Journal of Physics: Conference Series (Vol. 1440, No. 1, p. 012043). IOP Publishing. https://doi.org/10.1088/17426596/1440/1/012043

[12] Hill, H. C., \& Chin, M. (2018). Connections between teachers' knowledge of students, instruction, and achievement outcomes. American Educational Research Journal, 55(5), 1076-1112. https://doi.org/10.3102/0002831218769614

[13] Bruin, A. B., Kok, E. M., Lobbestael, J., \& de Grip, A. (2017). The impact of an online tool for monitoring and regulating learning at university: overconfidence, learning strategy, and personality. Metacognition and Learning, 12(1), 21-43.

[14] Suhandri,H dan Mardalena,T. (2013). Pengaruh Metode Pembelajaran Problem Solving Terhadap Hasil Belajar Matematika Ditinjau Dari Kemandirian Belajar. Jurnal Formatif. Vol 3 (2).

[15] Maltby, F. S., Gage NL, Berliner, D., \& David C. (2005). Educational Psychology: an Australia and New Zealand Perspectiv. Brisbane: Jhon Willey \& Sons.

[16] Aini, P.N. dan Taman, A. (2012). Pengaruh Kemandirian Belajar dan Lingkungan Belajar Peserta didik Terhadap Prestasi Belajar 
Akuntansi Peserta didik Kelas Xi Ips Sma Negeri 1 Sewon Bantul Tahun Ajaran 2010/2011. Jurnal Pendidikan Akuntansi Indonesia. Vol. X, No. 1.

[17] Anghileri, J. (2006). Scaffolding practices that enhance Mathematics learning. Journal of Mathematics Teacher Education, 9, 33-52.

[18] Adams R J \& Khoo S T 1996 QUEST: the interactive test analysis system version 2.1 (Victoria: The Australian Council for Educational Research)

[19] Sukardjo. (2012). Buku Pegangan Kuliah Evaluasi Pembelajaran IPA. Yogyakarta: Program Studi Pendidikan Sains Program Pascasarjana UNY.

[20] Boone, W. J., Staver, J. R., \& Yale, M. S. (2014). Rasch analysis in the human sciences. Dordrecht: Springer

[21] Sumintono, B., \& Widhiarso, W. (2015). Aplikasi Pemodelan Rasch pada Assessment Pendidikan. Cimahi: Trim Komunikata Publishing House.

[22] Arista, F. S., \& Kuswanto, H. (2018). Virtual Physics Laboratory Application Based on the Android Smartphone to Improve Learning Independence and Conceptual Understanding. International Journal of Instruction, 11(1), 1-16.

[23] Ferreira, J. B., Klein, A. Z., Freitas, A., \& Schlemmer, E. (2013). Mobile learning: definition, uses and challenges. Cutting-edge Technologies in Higher Education, 6, 47-82.

[24] Sidin, U. S. (2016). Penerapan Strategi Scaffolding pada Pembelajaran Pemrograman Web Di SMK Kartika Wirabuana 1. Publikasi Pendidikan, 6(3).

[25] Li, K. C., Lee, L. Y. K., Wong, S. L., Yau, I. S. Y., \& Wong, B. T. M. (2019). The effects of mobile learning for nursing students: an integrative evaluation of learning process, learning motivation, and study performance. International Journal of Mobile Learning and Organisation, 13(1), 51-67.

[26] Azevedo, R., \& Hadwin, A. F. (2005). Scaffolding self-regulated learning and metacognition-Implications for the design of computer-based scaffolds. Instructional Science, 33(5), 367-379.

[27] Tiantong, M., \& Teemuangsai, S. (2013). The Four Scaffolding Modules for Collaborative Problem-Based Learning through the Computer Network on Moodle LMS for the Computer Programming Course. International Education Studies, 6(5), 47-55.

[28] Chavoshi, A., \& Hamidi, H. (2019). Social, individual, technological and pedagogical factors influencing mobile learning acceptance in higher education: A case from Iran. Telematics and Informatics, 38, 133-165. 